\title{
Pengelolaan Sampah Berbasis Masyarakat
}

\author{
Yunita Ismail \\ Program Studi Teknik Lingkungan, Universitas Presiden, yunitaismail@president.ac.id
}

\begin{abstract}
ABSTRAK
Pengelolaan sampah berbasis masyarakat merupakan salah satu upaya untuk mengurangi dan mengelola sampah. Rumah tangga sebagai bagian dari masyarakat merupakan salah satu produsen sampah. Rumah tangga dapat mengurangi dan memanfaatkan kembali sampahnya bahkan memberikan pendapatan tambahan. Untuk membuat masyarakat berperan aktif dan berkesinambungan dalam pengelolaan sampah diperlukan organisasi yang beranggotakan masyarakat dan menjalankan pengelolaan dan pemanfaatan sampah secara bersama dan akan memberikan bermanfaat bersama. Dari kegiatan pengabdian masyarakat yang telah dilakukan, masyarakat memberikan respon positif untuk mengelola sampah, hanya perlu dibuat kelembagaan yang akan menjaga keberlanjutan pengelolaan tersebut. Kegiatan pengelolaan sampah diberikan pada partisipan yang merupakan pemilik rumah, berpendidikan SD dan tergolong berumur produktif (31-40 tahun).
\end{abstract}

Kata-kata Kunci: Sampah, Rumah Tangga, Pengelolaan, Masyarakat, Kelembagaan

\begin{abstract}
Community-based waste management is an effort to reduce and manage waste. The community, where the household is a part of it as one of the waste producers can reduce and reuse their waste and even provide an additional income. To make the community plays an active and continuous role in a waste management, an organization with community members is needed to run the management and utilize waste together, which will provide mutual benefits. From the community service activities that have been carried out, the community gives a positive response on managing waste. Institutions are needed to be made to maintain the sustainability of the waste management. Waste management activities are given to the parties who are homeowners, those who have an elementary education and those who are in a productive age (31-40 years).
\end{abstract}

Keywords: Waste, Household, Management, Community, Institution

\section{PENDAHULUAN}

Definisi sampah menurut Undang Undang No. 18 Tahun 2008 adalah sisa kegiatan sehari-hari manusia dan/atau proses alam yang berbentuk padat. Pembeda sampah dari limbah yang lain adalah bentuknya yang padat. Jadi limbah yang berbentuk padat disebut sampah. Jumlah sampah yang dihasilkan atau biasa disebutkan sebagai jumlah timbulan sampah, semakin hari semakin bertambah, baik jumlah maupun jenisnya.

Sampah dapat dihasilkan dari kegiatan produksi maupun kegiatan konsumsi, berarti dapat dihasilkan oleh produsen maupun konsumen. Upaya pengelolaan sampah pada kegiatan produksi dilakukan terutama dalam rangka meningkatkan produktifitas, terutama produktifitas input material yang digunakan. Dari sisi konsumsi, sumbangan konsumen terhadap timbulan sampah otomatis akan bertambah dengan bertambahnya jumlah manusia. Jumlah timbulan sampah meningkat tidak hanya dalam jumlah, tetapi juga pada jenisnya. Pertambahan jumlah penduduk memberikan kontribusi peningkatan timbulan sampah dalam jumlah maupun dalam jenis. Jenis sampah yang dihasilkan ditentukan oleh pola konsumsi dan perilaku penduduk dalam mengelola sampah. 
Dari data di 6 kota metropolitan, 41 kota sedang dan 82 kota kecil yang tersebar di seluruh Indonesia pada tahun 2015, diperoleh bahwa jumlah timbulan sampah per jiwa adalah $0.8 \mathrm{~kg} / \mathrm{hari}$ (KLHK, 2017). Jika menggunakan jumlah penduduk Indonesia pada bulan Juli 2017, yaitu 262 juta jiwa, berarti setiap hari akan dihasilkan sampah sebesar 209.600 ton atau dalam seminggu 1,5 juta ton. Jumlah sampah ini sangat besar, dan yang sebenarnya akan lebih besar karena perkiraan itu hanya dari sebagian kota di Indonesia. Oleh karena itu pengelolaan sampah dari masyarakat menjadi sangat penting dan mendesak (urgent).

Selain jumlah yang dihasilkan dari konsumer sangat tinggi, dalam pengelolaan sampah yang dihasilkan konsumen terdapat kesulitan lain, yaitu kelembagaannya. Hal ini mengingat bahwa antar konsumen tidak ada organisasi yang menyatukannya, tidak seperti produser yang memiliki organisasi perusahaan. Padahal pengelolaan sampah harus dilakukan bersama-sama. Kelembagaan pengelolaan sampah dari konsumen menjadi organisasi yang akan melaksanakan fungsi pengelolaan tersebut. Masyarakat harus berpartisipasi dalam mengelolaan sampah, mengingat sampah dihasilkan setiap hari dan pengelolaannya harus dilakukan secara bersama-sama.

Jenis sampah yang dihasilkan konsumen mengalami perubahan seiring terjadinya perubahan pola konsumsi masyarakat. Penggunaan bahan tidak terurai (non degradable) menggantikan bahan terurai (degradable) dalam membungkus makanan, merupakan salah satu perubahan pola konsumsi yang menyebabkan peningkatan sampah yang tidak terurai. Perubahan komposisi sampah plastik dari tahun 2013 (14\%) menjadi 16 persen pada tahun 2016, dan sampah organik dari 60 persen pada tahun 2013 menjadi 57 persen pada tahun 2016 (KLHK, 2017).

Menurut Undang-Undang Nomor 18 Tahun 2008 dan Peraturan Pemerintah Nomor 81 Tahun 2012, pengelolaan sampah adalah kegiatan yang sistematis, menyeluruh, dan berkesinambungan yang meliputi pengurangan dan penanganan sampah. Adapun tujuan pengelolaan sampah adalah untuk meningkatkan kesehatan masyarakat dan kualitas lingkungan serta menjadikan sampah sebagai sumberdaya.

Permasalahan utama pengelolaan sampah di Indonesia terjadi pada saat sampah diangkut dari rumah tangga ke tempat pengumpulan sampah. Pada tingkat rumah tangga upaya pemisahan sampah sudah mulai dilakukan, walaupun belum merata di seluruh wilayah Indonesia. Akan tetapi pada saat sampah diangkut ke tempat pengumpulan akhir, seringkali sampah dicampurkan kembali, karena armada pengangkutnya tidak membedakan sampah berdasarkan jenis/bahannya.

Sampah rumah tangga dapat dikelompokkan berdasarkan bahannya, seperti kertas, plastik, kaleng, kaca dan sampah organik. Sampah kaleng dan kaca dapat digunakan sebagai material input bagi industri kaleng dan kaca. Pemanfaatan sampah kaleng dan 
kaca ini membutuhkan pengumpulan terlebih dahulu agar dicapai jumlah ekonomis untuk dimanfaatkan kembali. Sampah kertas, plastik dan sampah organik dapat dimanfaatkan sebagai sumber energi dengan menggunakan teknologi tertentu. Selain itu sampah plastik dan sampah organik juga memungkinkan untuk dijadikan sumberdaya material input pada suatu kegiatan produksi.

Kegiatan pengabdian kepada masyarakat ini bertujuan:

(a) Menginisiasi pembentukan organisasi pengelolaan sampah di tingkat RT

(b) Melakukan penyuluhan tentang pengelolaan sampah yang dapat dilakukan oleh masyarakat;

(c) Membangun kerjasama dengan pihak-pihak terkait dalam pengelolaan sampah rumah tangga.

Kegiatan pengabdian masyarakat ini dilaksanakan di Perumahan Cikarang Baru, RT 01 Kelurahan Mekar Mukti Kecamatan Cikarang Utara dan di RT 03 Desa Jatireja, Kecamatan Cikarang Barat, Bekasi.

\section{METODE PELAKSANAAN}

Kegiatan pengabdian masyarakat ini terdiri dari 2 kegiatan untuk menjawab dua tujuan yang telah ditetapkan. Kegiatan1 adalah persiapan kegiatan inisiasi untuk membentuk organisasi/lembaga pengelolaan sampah di tingkat RT. Kegiatan ini dimulai dengan mengadakan pertemuan dengan Pengurus RT dan melakukan penyesuaian organisasi yang akan dibentuk dengan organisasi RT yang sudah ada. Sebelum rapat dengan seluruh pengurus RT, dilakukan pendekatan dengan Ketua RT terlebih dahulu, agar tujuan yang ingin disampaikan pada kegiatan ini dapat dimengerti dengan baik. Pendekatan juga dilakukan kepada Ketua Pengajian Ibu-ibu RT.

Persiapan yang lain adalah dilakukan observasi mengenai pengelolaan sampah yang sekarang sudah berjalan, dan kekurangan yang dapat diperbaiki. Observasi juga dilakukan terhadap masyarakat sekitar, terutama dalam cara yang digunakan untuk menangani sampah rumah tangga mereka.

Kegiatan kedua adalah kegiatan untuk memenuhi tujuan kedua, yaitu memberikan penyuluhan kepada masyarakat mengenai pengelolaan sampah. Kegiatan ini dilaksanakan bersama dengan mahasiswa. Mahasiswa mempersiapkan materi penyuluhan yang akan disampaikan, termasuk mempersiapkan poster dan stiker yang akan digunakan pada saat penyuluhan kepada masyarakat dilaksanakan.

Masyarakat yang akan dikunjungi adalah ibu-ibu rumah tangga yang merupakan pihak yang paling bertanggungjawab terhadap pengelolaan sampah di rumahnya. Kontak dengan masyarakat dilakukan melalui bidan yang bertempat tinggal di RT yang dipilih. Kontak dan 
diskusi dengan bidan yang merupakan tokoh masyarakat dilakukan untuk memastikan bahwa bahan penyuluhan yang akan diberikan dapat dengan mudah dimengerti oleh masyarakat.

\section{HASIL DAN PEMBAHASAN}

Kegiatan pengabdian masyarakat ini dilakukan di dua tempat berbeda dan diwaktu yang juga berbeda. Kegiatan pertama dilakukan di RT 01, Kelurahan Mekar Mukti dan kegiatan kedua di RT 03 Desa Jatireja.

\section{(a) Kegiatan Pertama}

Kegiatan pengabdian ini dimulai dengan mengadakan rapat dengan pengurus RT 01, yang dilaksanakan di kediaman Ketua RT dan pengurus yang hadir adalah Wakil Ketua RT, Sekretaris RT, dan Bendahara RT (Gambar 1). Rapat dilaksanakan pada malam hari, karena para pengurus RT adalah para bapak yang bekerja di siang hari.

Rapat berlangsung santai dan banyak diperoleh permasalahan dan kondisi terkini seputar pengelolaan sampah yang sudah dilakukan. Adapun beberapa permasalahan dalam pengelolaan sampah yang diperoleh adalah:

i. Seharusnya pengumpulan dan pengangkutan sampah dilakukan dua kali seminggu, tetapi pada kenyataannya, seringkali pengumpulan dan pengangkutan sampah dilakukan sekali seminggu. Hal ini membuat kondisi jalan dan lingkungan sekitar menjadi tidak sehat dan terlihat sangat kotor (Gambar 2).

ii. Di RT 1 ini banyak terdapat kost-an atau rumah yang dijadikan usaha kost-an. Hal ini membuat jumlah sampah yang dihasilkan lebih banyak, karena satu kost-an dapat dihuni oleh sekitar 10 - 15 orang.

iii. Sampah plastik sudah dikumpulkan oleh beberapa orang, dan dijual sebagai pendapatan bagi pengumpul tersebut. Pengelolaan ini tidak dilakukan oleh seluruh rumah sehingga tidak memberikan manfaat kepada masyarakat secara bersama. Jika akan dilakukan pengumpulan bersama untuk semua rumah, maka dibutuhkan untuk mengumpulkannya sebelum sampah plastik tersebut dijual kepihak ketiga.

iv. Pengelolaan sampah organik memerlukan tempat untuk melakukan pengelolaan. Sangat diharapkan agar pengelolaan sampah organik dapat dilakukan pada luasan tanah sempit atau dilakukan pada setiap rumah, untuk memperoleh pupuk.

Dari rapat dengan Pengurus RT ini diputuskan bahwa keorganisasian untuk pengelolaan sampah akan dimasukkan sebagai bagian kepengurusan RT dan diserahkan kepada ibu-ibu. Akan tetapi, keputusan sepenuhnya diserahkan kepada ibu-ibu, karena yang akan melaksanakan pengelolaan sampah tersebut adalah ibu-ibu. Untuk pertemuan 
dengan ibu-ibu disarankan untuk hadir diacara arisan yang dilakukan setiap bulan. Pada acara arisan ini ibu-ibu akan berkumpul dan melakukan penarikan arisan.

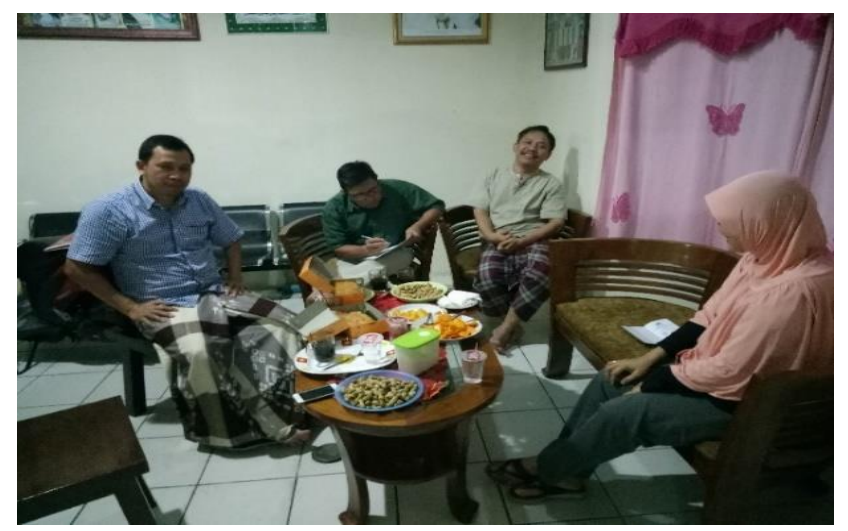

Gambar 1

Rapat dengan Pengurus RT di Kediaman Ketua RT

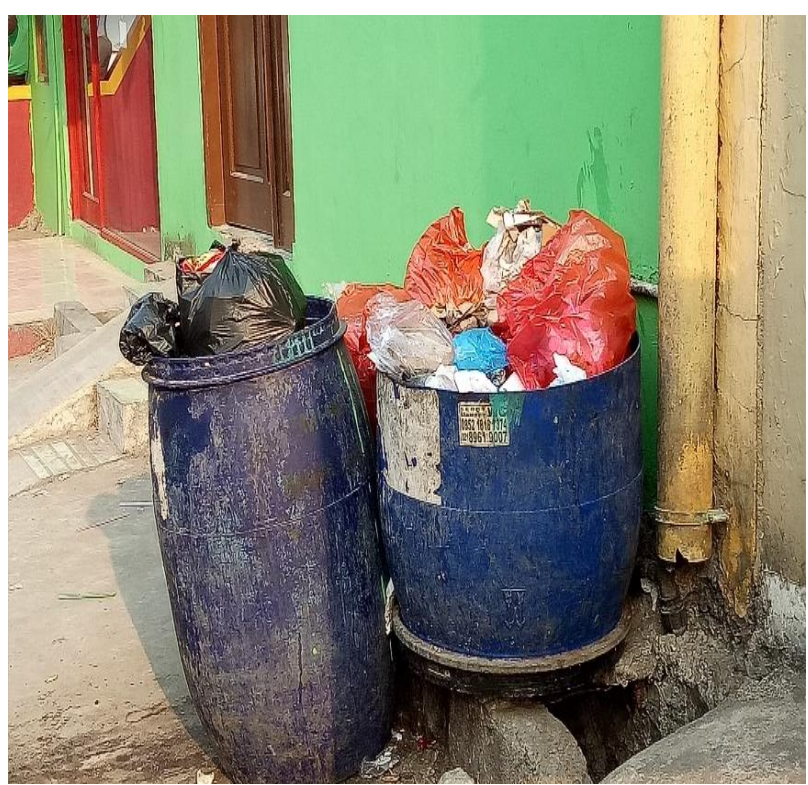

Gambar 2

Kondisi Tempat Sampah di Pinggir Jalan Perumahan

Kelembagaan masyarakat mempunyai keterkaitan kuat dengan kondisi tekno-sosial masyarakat (Wardi, 2011). Oleh karena peranan pemimpin menjadi penting untuk pembentukan lembaga masyarakat. Pada kegiatan pengabdian masyarakat ini digunakan Pengurus RT, terutama Ketua RT sebagai pemimpin yang diangkat masyarakat. Diharapkan dengan memaksimumkan peran Pengurus RT dalam melaksanakan pelayanan kepada masyarakat, agar lembaga pengelolaan masyarakat ini dapat berkelanjutan.

Setelah berdiskusi dengan Pengurus RT, dilaksanakan pertemuan dengan ibu-ibu yang ada di RT 01. Pertemuan ini dilakukan pada acara arisan bulanan yang dilakukan di 
rumah salah satu warga di Jl. Kedasih 1 (Gambar 3). Pada pertemuan dengan ibu-ibu ini diperoleh beberapa hasil sebagai berikut:

i. Di awal terlihat ketidak-yakinan dari ibu-ibu bahwa program ini akan berjalan dengan baik dan berkesinambungan. Setelah dilakukan dengar pendapat dan diberikan contohcontoh pengelolaan sampah di tempat lain yang sudah berhasil, akhirnya ibu-ibu tersebut setuju untuk melakukan pengelolaan sampah. Bentuk organisasi pengelolaannya tidak mengikat dan lebih didasari oleh keinginan sendiri atau sukarela.

ii. Setelah berdiskusi dan bertukar pikiran mengenai masalah sampah yang selalu terjadi, akhirnya ibu-ibu RT 01 ini bersedia untuk membuat organisasi pengelolaan sampah di sekitar rumah mereka dan organisasi yang dibuat ini menempatkan pengurus RT sebagai pelindung, bukan pelaksana.

iii. Ibu-ibu RT 01 lebih berminat untuk melakukan pengelolaan sampah organik dan mendapatkan pupuk kompos yang bisa digunakan untuk bercocok tanam. Akan tetapi pertimbangan bahwa akan dibutuhkan tempat yang tertentu/luas jika harus melakukan pengelolaan bersama, yang memungkinkan adalah melakukan pengelolaan sampah organik pada skala rumah tangga.

iv. Untuk pengumpulan sampah plastik, terdapat kekhawatiran tidak ada tempat untuk mengumpulkannya, sehingga dirasa perlu untuk bekerjasama dengan para bapak-bapak untuk penyediaan tempat tersebut. Akan tetapi untuk jangka pendek, pengumpulan dan menjual sampah plastik adalah kegiatan yang bisa langsung dilaksanakan.

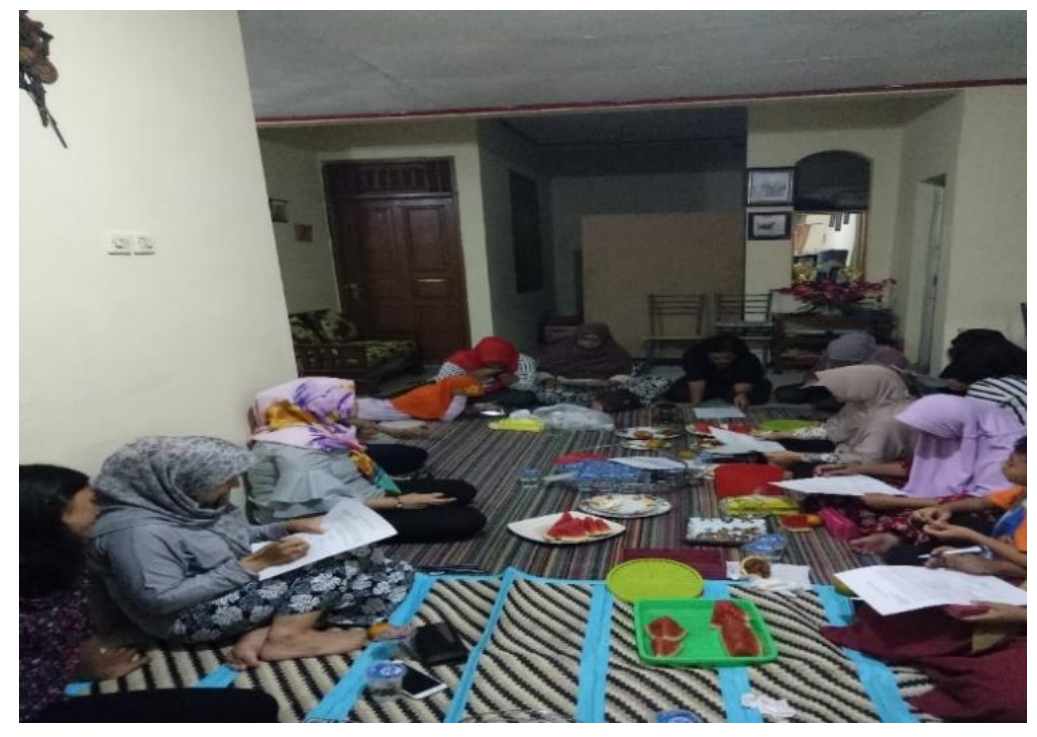

Gambar 3

Suasana Arisan Ibu-ibu RT 01 
Pada pertemuan ini belum dibentuk pengurus organisasi pengelolaan sampah, tetapi ditunjuk Ibu Alfan sebagai koordinator. Setelah diskusi selesai, dibagikan kuesioner kepada para peserta untuk menampung aspirasi semua yang hadir. Kegiatan pengelolaan sampah ini akan dilaksanakan, tetapi tidak dengan penjadwalan yang ketat atau berturut-turut, karena kegiatan dari masing-masing ibu sudah sangat padat. Oleh karena itu, agenda selanjutnya akan disesuaikan dengan jadwal arisan di bulan selanjutnya. Pertemuan arisan akan digunakan sebagai media komunikasi dan pertemuan untuk pengelolaan sampah.

\section{(b) Kegiatan Kedua}

Kegiatan kedua dilaksanakan di Desa Jatireja bersama-sama dengan mahasiswa. Pelaksanaan kegiatan ini dilakukan bersamaan dengan kegiatan penyuluhan mengenai sanitasi dan kesehatan masyarakat. Dalam kegiatan ini, mahasiswa memberikan penyuluhan mengenai pemanfaatan sampah rumah tangga, yaitu sampah plastik (Gambar 4).

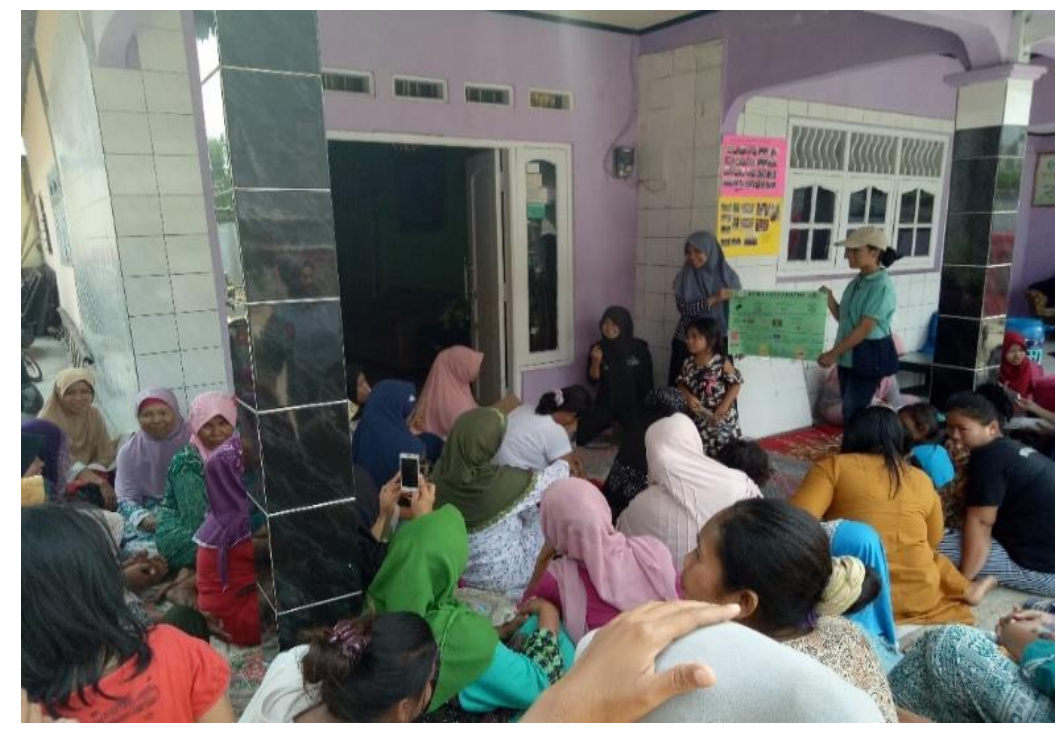

Gambar 4

Pemberian Penyuluhan mengenai Pemanfaatan Sampah Plastik Skala Rumah Tangga oleh Mahasiswa

Penyuluhan pengelolaan sampah sudah dikhususkan untuk sampah plastik. Lokasi yang dipilih juga bukan di perumahan, tetapi di perkampungan masyarakat sekitar perumahan. Pemilihan lokasi dilakukan dengan pertimbangan bahwa masyarakat sudah banyak yang melakukan pengumpulan sampah plastik. Untuk sampah plastik yang bernilai ekonomis, sudah langsung dijual kepada agen (pengumpul), tetapi untuk sampah plastik yang tidak dapat dijual, belum terjual dan sudah semakin menumpuk.

Oleh karena itu, penyuluhan pengelolaan sampah yang dilakukan adalah pemanfaatan sampah plastik menjadi barang yang lebih berguna. Materi penyuluhan yang diberikan, 
seperti pembuatan kursi dari botol air mineral bekas, dan pembuatan hiasan dinding dari plastik bungkus kopi (sachet). Dalam penyuluhan ini juga disampaikan jika ingin membuat barang-barang lain juga dimungkinkan karena yang diajarkan adalah membuat bahan pembuat hiasan, yaitu menjalin bungkus plastik tersebut menjadi bahan untuk membuat hiasannya sendiri.

Melihat respon dari partisipan terhadap pengelolaan sampah pada kedua kegiatan di atas, maka dirasa perlu untuk mencari kerjasama dengan pihak-pihak lain yang dapat membantu pelaksanaan pengelolaan sampah bagi masyarakat ini. Oleh karena itu dilakukan kunjungan ke Bapelkes (Balai Penlatihan dan Kesehatan) yang berlokasi di Lemahabang, Cikarang.

Dari kunjungan ke Bapelkes, diperoleh bahwa lembaga ini telah memiliki teknologi pengelolaan sampah organik berskala rumah tangga. Teknologi ini dirasakan sangat cocok dengan kebutuhan pengelolaan sampah di rumah tangga. Bapelkes juga bersedia untuk menyediakan pelatihan untuk menggunakan alat pengelolaan sampah, yaitu alat pembuatan pupuk cair dari sampah organik rumah tangga. Alat pembuatan pupuk cair dari sampah organik skala rumah tangga dari Bapelkes ditampilkan Gambar 5.

Dari respon masyarakat terlihat bahwa pengetahuan mengenai pengelolaan sampah dan mendapatkan manfaat dari sampah sudah dimiliki oleh partisipan. Upaya pengumpulan sampah plastik, sudah dilakukan tetapi hanya pada sampah plastik yang bernilai ekonomi, atau yang dapat dijual saja. Untuk sampah plastik yang tidak bernilai ekonomi (tidak laku dijual) belum dilakukan pengelolaan.

Dari keseluruhan partisipan pada kegiatan pengabdian ini (di 2 RT) diperoleh karakteristik sosial ekonomi sebagaimana ditampilkan pada Tabel 1. Partisipan paling banyak dari golongan umur $31-40$ tahun $(39,5 \%)$, ibu rumah tangga $(86,8 \%)$, pendidikan SD $(31,6 \%)$ dan rumah yang tinggal di rumah sendiri $(84,2 \%)$. Dari karakteristik kebanyakan partisipan ini dapat dikatakan bahwa partisipan adalah ibu-ibu rumah tangga dengan pendidikan rendah, pemilik rumah dan berumur produktif. Partisipan kegiatan pengelolaan sampah dari tingkat pendidikan rendah adalah hal yang baru, karena seperti hasil penelitian program daur-ulang di Malaysia (Zen, Zainura dan Rafiu, 2014) responden yang berpartisipasi adalah responden dengan pendidikan tinggi, memiliki tingkat pendapatan tinggi dan pemilik rumah.

Akan tetapi jika dilihat dari penelitian di Nepal mengenai keinginan membayar dari masyarakat terhadap pengelolaan sampah (Maskey dan Mrinila, 2017), tingkat pendidikan responden adalah sekitar 7 tahun pendidikan formal, atau dapat dikatakan tamat SD. Responden pada penelitian ini juga merupakan masyarakat yang merupakan pemilik rumah. 


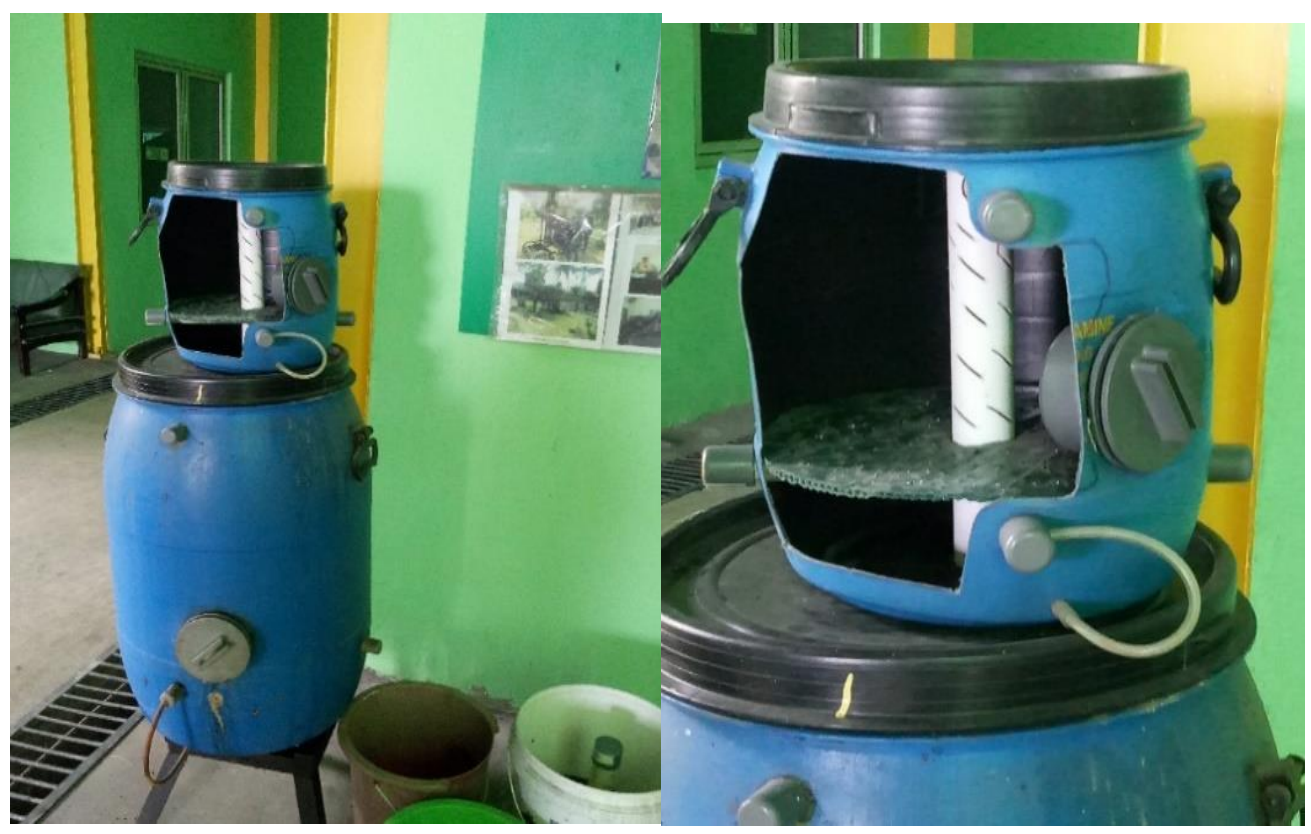

\section{Gambar 5}

Alat Pembuatan Pupuk Cair dari Sampah Organik Rumah tangga

Dari partisipan pada kegiatan pengabdian ini, didapat bahwa 57,9\% menyatakan mengetahui tentang pengelolaan sampah dan sisanya $(42,1 \%)$ menyatakan tidak mengetahui (Gambar 6). Pengetahuan mengenai pengelolaan sampah ini diperoleh partisipan dari berbagai sumber, seperti, media, teman atau lainnya, seperti dari spanduk atau selebaran, akan tetapi tidak ada yang memperoleh pengetahuan pengelolaan sampah dari pemerintah (Gambar 7). Gambar 7 menunjukkan bahwa sumber terbanyak yang digunakan partisipan adalah lainnya, yaitu media iklan, baik cetak maupun online merupakan sumber pengetahuan, termasuk juga melalui media sosial, seperti whatsapp atau line.

Kegiatan pengelolaan sampah dikategorikan menjadi komposting (untuk sampah organik), pemilahan sampah (untuk sampah non organik) dan pengumpulan sampah ekonomis. Sebaran partisipan untuk kegiatan pengelolaan sampah ini ditampilkan Gambar 8. Kegiatan komposting, paling sedikit dipilih (2,6\%), dan paling banyak adalah pengumpulan sampah bernilai ekonomis. Pengumpulan sampah ekonomis ini sudah dilakukan oleh partisipan dan sudah ada agen yang akan menampung (membeli) sampah tersebut. 
Tabel 1

Karakteristik Sosial Ekonomi Partisipan

\begin{tabular}{|c|c|c|}
\hline Variabel & Frekuensi & $\%$ \\
\hline Umur & & \\
\hline 20 - 30 tahun & 9 & 23.7 \\
\hline Lebih dari 40 tahun & 15 & 39.5 \\
\hline Pekerjaan & 14 & 36.8 \\
\hline Ibu rumah tangga & & \\
\hline Karyawan Swasta & 33 & 86.8 \\
\hline Pengawai Negeri & 2 & 5.3 \\
\hline Wiraswasta & 1 & 2.6 \\
\hline Kepemilikan Rumah & 2 & 5.3 \\
\hline Rumah sendiri & & \\
\hline Sewa/Kontrak & 32 & 84.2 \\
\hline Rumah Perusahaan & 3 & 7.9 \\
\hline Tingkat Pendidikan & 3 & 7.9 \\
\hline SD & & \\
\hline SMP & 12 & 31.6 \\
\hline SMA & 6 & 21.1 \\
\hline Diploma & 3 & 15.8 \\
\hline Sarjana & 1 & 7.9 \\
\hline Lainnya & 8 & 21.1 \\
\hline
\end{tabular}

Sumber: Data Primer

\section{Pengetahuan Pengelolaan Sampah}

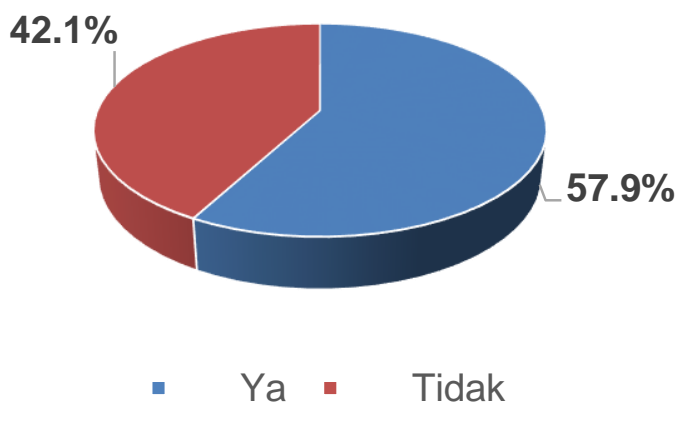

Gambar 6

Sebaran Partisipan menurut Pengetahuan tentang Pengelolaan Sampah 


\section{Sumber Pengetahuan Pengelolaan Sampah}

$36,8 \%$

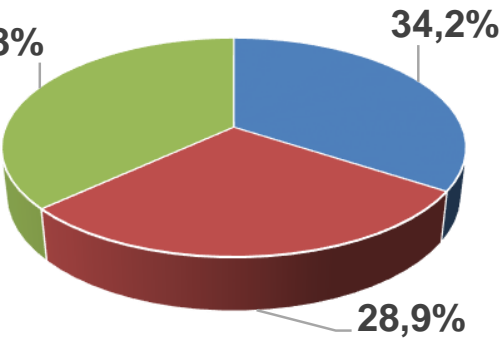

- Media - Teman - Lainnya

Gambar 7

Sebaran Partisipan menurut Sumber Pengetahuan Pengelolaan Sampah

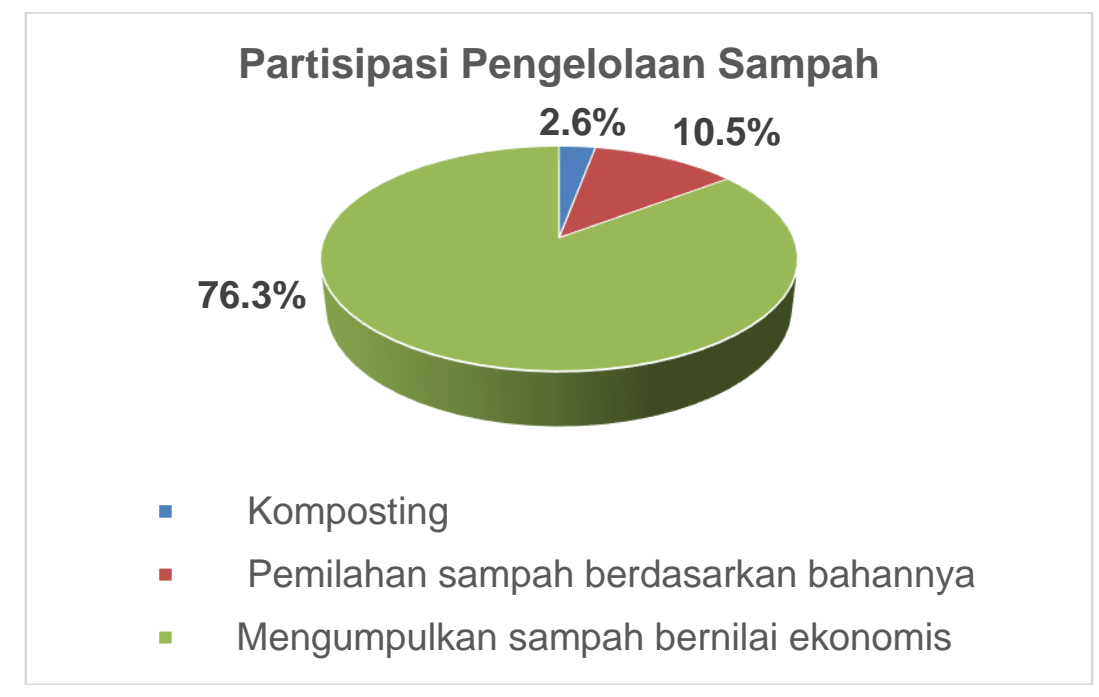

Gambar 8

Sebaran Partisipan menurut Partisipasi dalam Kegiatan Pengelolaan Sampah

Partisipasi dalam pengelolaan sampah ini dipahami masih berupa kesadaran akan perlunya pengelolaan sampah. Selain dari kegiatan komposting, pemilahan dan pengumpulan sampah ekonomis, pemanfaatan sampah juga dapat dilakukan dengan mendaur-ulang sampah. Keinginan mendaur-ulang sampah ini terlihat pada sebaran jawaban partisipan kesediaan untuk mendaur-ulang sampah, seperti disajikan Gambar 9.

Partisipan tertarik untuk memanfaatkan kembali sampah, terutama sampah plastik untuk menjadi barang-barang yang berguna, apalagi jika bisa memberikan pendapatan. Akan tetapi, bisnis pemanfaatan sampah ini haruslah memenuhi skala ekonomi yang memadai untuk dapat memberikan profit. Oleh karena itu pendaurulangan sampah harus dilakukan secara bersama-sama. 


\section{Kesediaan Partisipan Mendaur-ulang Sampah}

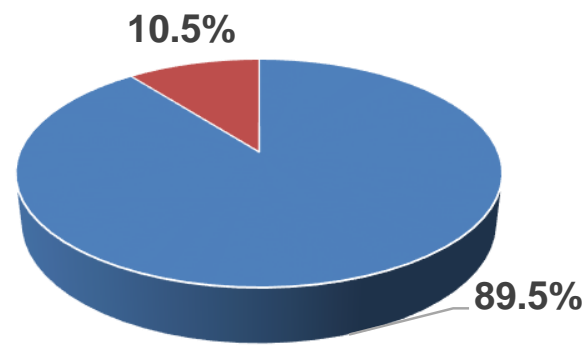

- Ya - Tidak

\section{Gambar 9}

Sebaran Partisipan menurut Kesediaan untuk Mendaurulang Sampah

Kesediaan sebagian besar (89,5\%) partisipan untuk mendaur-ulang sampahnya, haruslah diikuti dengan upaya pendaur-ulangan itu sendiri. Dari kunjungan ke Bapelkes Cikarang, diproleh bahwa Bapelkes telah memiliki alat pembuatan puput cair dari sampah organik skala rumah tangga. Alat pembuatan pupuk cair ini sangat mudah dibuat dan mudah digunakan, serta Bapelkes memiliki paket pembelajaran untuk membuatnya.

\section{Frekuensi Pengumpulan Sampah}

$36.8 \%$ $28.9 \%$

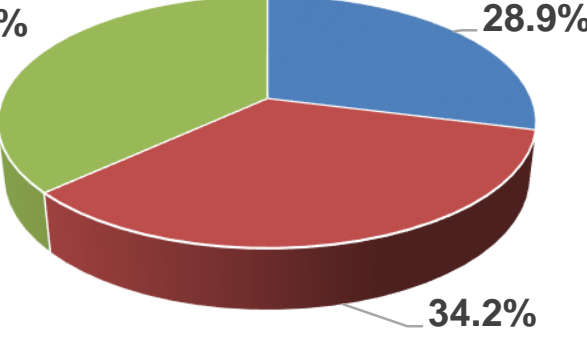

- $1 x$ seminggu - $2 x$ seminggu

- $>2 x$ seminggu

Gambar 10

Sebaran Partisipan berdasarkan Frekuensi Pengumpulan Sampah

Kegiatan pengambilan sampah dari rumah tangga, paling banyak $(36,8 \%)$ menginginkan lebih dari 2 kali seminggu (Gambar 10). Pengumpulan sampah yang lebih sering ini disebabkan untuk menghindari penumpukan sampah di sekitar rumah. Tumpukan 
sampah merupakan sumber penyakit, selain juga menimbulkan bau yang tidak sedap. Oleh karena itu, agar pengumpulan sampah dapat sering dilkaukan, 55,3\% partisipan bersedia mengumpulkan sampah ekonomisnya sendiri (Gambar 11).

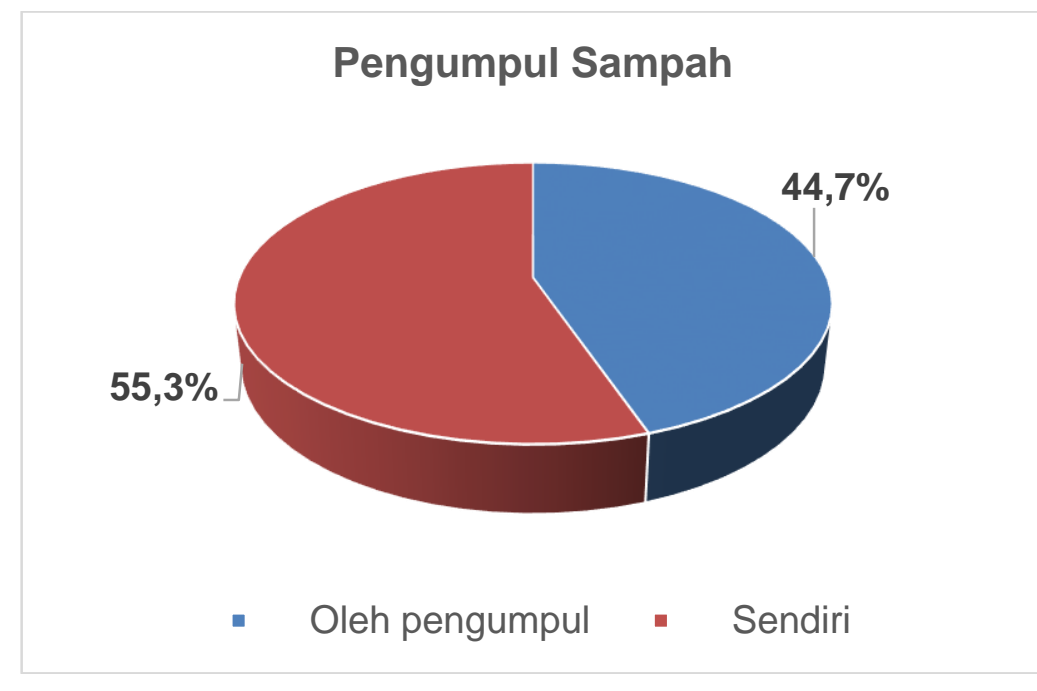

Gambar 11

Sebaran Partisipan berdasarkan Pengumpul Sampah

\section{KESIMPULAN}

Kesimpulan dari kegiatan pengabdian masyarakat yang dilakukan di dua tempat berbeda ini adalah sebagai berikut:

(a) Pengelolaan sampah sudah ada yang dilaksanakan masyarakat, tetapi masih secara sendiri-sendiri, sehingga belum terlihat manfaatnya terutama manfaat ekonomi;

(b) Pengelolaan sampah berbasis masyarakat perlu dilakukan, mengingat sampah akan terus dihasilkan dan yang paling bertanggung jawab untuk melakukan pengelolaan adalah masyarakat itu sendiri.

(c) Pengelolaan sampah dapat dilakukan dengan memanfaatkan teknologi yang sudah ada, misalnya dari Bapelkes Cikarang

\section{UCAPAN TERIMA KASIH}

Dalam kesempatan ini penghargaan dan rasa terimakasih disampaikan kepada Lembaga Riset dan Pengabdian Masyarakat Universitas Presiden yang telah mendanai kegiatan pengabdian masyarakat ini. Kegiatan pengabdian masyarakat ini merupakan upaya yang harus dilakukan secara berkesinambungan mengingat dampak dari aktifitas pengabdian ini seharusnya dapat meningkatkan kesadaran dan pengetahuan masyarakat terhadap pengelolaan sampah. 


\section{REFERENSI}

Kementerian Lingkungan Hidup dan Kehutanan (KLHK). (2017). Data Sampah Kota. Jakarta: KLHK.

Maskey, B \& Mrinila S. (2017). Households' Willingness to Pay for Improved Waste Collection Service in Gorkha Municipality of Nepal. Environments, 4 (77). Diunduh dari www.mdpi.com/journal/environment

Peraturan Pemerintah No. 81 Tahun 2012 Tentang Pengelolaan Sampah Rumah Tangga dan Sampah Sejenis Sampah Rumah Tangga.

Undang-undang No. 18 Tahun 2008 Tentang Pengelolaan Sampah.

Wardi, I N. (2011). Pengelolaan Sampah Berbasis Sosial Budaya: Upaya Mengatasi Masalah Lingkungan di Bali. Jurnal Bumi Lestari, 11(1).

Zen, I.S., Zainura, Z.N., \& Rafiu, O.Y. (2014). The Profiles of Household Solid Waste Recyclers and Non-recyclers in Kuala Lumpur, Malaysia. Habitat International, No 42. Diunduh dari www.elsevier.com/locate/habitatint 